\title{
Assessment of farmers' compliance in implementing recommended cow comfort changes and their effects on lying time, stall and cow cleanliness within smallholder dairy farms in Kenya
}

\author{
Emily K. Kathambi ${ }^{a,{ }^{*}, \text { John A. VanLeeuwen }}{ }^{a}$, George K. Gitau ${ }^{b}$ and Crawford W. Revie ${ }^{c}$ \\ ${ }^{\text {a }}$ Department of Health Management, Atlantic Veterinary College, University of Prince \\ Edward Island, Canada \\ ${ }^{\mathrm{b}}$ Department of Clinical Studies, Faculty of Veterinary Medicine, University of Nairobi, \\ Kenya \\ ${ }^{\mathrm{c}}$ Department of Computer and Information Sciences, University of Strathclyde, Scotland \\ *Corresponding author email: kiuguek@gmail.com
}

\begin{abstract}
Our study aimed to evaluate farmers' compliance in implementing recommendations of farmspecific cow comfort changes, and the effects of these changes on lying time, stall cleanliness and cow cleanliness using a randomized controlled trial carried out on 100 smallholder dairy farms in Kenya, with 62 and 11 farms remaining in the intervention and control groups, respectively.

On the first farm visit, data loggers were attached on lactating cows to determine lying time and questionnaires utilized to collect baseline data. Three days later, stall design and management recommendations were given to the intervention group of farmers orally and in written form. After an average of 39 \pm 7 days, data loggers were re-attached, compliance was assessed, and a postintervention questionnaire was administered to the intervention group on the third visit. Three days subsequent to the first and third visits, data loggers were removed from all cows.

Data were analysed in Stata $14.2 ®$ using proportion tests and Kruskal-Wallis rank tests to compare cleanliness scores and lying time, respectively. Interaction effects between treatment groups and visits were assessed using multivariable mixed linear and logistic regression models. While 46 of the 62 intervention farmers (74\%) made at least one recommended change to cow comfort, $63 \%$ of the 324 overall recommendations were implemented. The odds of a recommendation being implemented were significantly higher when:1) major recommendations were given relative to minor recommendations $(\mathrm{OR}=6.28)$; 2) recommendations were related to floor characteristics (floor softness and flatness) in comparison to recommendations related to stall design $(\mathrm{OR}=3.14)$. The odds of compliance were lower on: 1) farms where the farm-hands received the
\end{abstract}


recommendations compared to farms that had the female principal farmer receive the recommendations $(\mathrm{OR}=0.01)$; 2 ) farms that had recommended changes related to roof, alley and sharps fixes relative to stall design fixes $(\mathrm{OR}=0.13)$. Post-intervention, stall, udder and upper hindleg cleanliness scores improved significantly ( $\mathrm{p}<0.0001, \mathrm{p}=0.021$ and $\mathrm{p}=0.017$, respectively) in the intervention farms but not in the control farms. There was no significant difference in lying times between intervention and control farms, with 0.6 and 0.2 hour/day increases being recorded in the intervention and control groups, from the 10.9 and 10.4 hours/day at baseline, respectively.

Giving farm-specific cow comfort recommendations to smallholder dairy farmers in Kenya, and providing them with a participatory role in the formulation and implementation of improvement recommendations ensured good acceptance and a high degree of implementation, and led to a subsequent improvement in cow comfort and cleanliness.

Keywords: compliance, cow comfort, welfare, stall design 


\section{Introduction}

With the rapid growth of the dairy industry globally, concerns about the welfare of dairy cows have been raised (Rollin, 2004) and a number of welfare standards have been set by various participants in the dairy industry (Rushen et al., 2011). These animal welfare standards include requirements for stall dimensions and management practices that are based on research findings (Bickert, 2000; Tucker et al., 2004). Tools used for assessment of welfare on dairy farms have been developed and used in various parts of the world to assure consumers of humane treatment of animals and to identify critical aspects of cow comfort that need to be addressed on farms (Vasseur et al., 2015).

Researchers have shown that stall configuration and dimensions, such as stall length and width (Tucker et al., 2004), neck rail positioning (Tucker et al., 2005) and brisket board availability (Tucker et al., 2006), in addition to management practices, such as frequent new bedding provision (Fregonesi et al., 2007), influence lying patterns of cows, an indicator of cow comfort and animal welfare (Cook et al., 2005). Findings indicate that stall and cow cleanliness are also influenced by stall design (Bernardi et al., 2009), as well as management practices such as bedding availability (Norring et al., 2008) and frequency of manure removal (DeVries et al., 2012).

In an effort to improve animal welfare on dairy farms, approaches have included education of farmers, legislation, and/or voluntary programs of encouragement of farmers to implement change (Whay and Main, 2015). For example, transfer of knowledge to farmers using a top-down approach was used to introduce a lameness control plan on UK dairy farms, but the implementation rates of components of the control plan were poor (Bell et al., 2009). However, in 2012, a 12\% decrease in lameness prevalence was reported in UK dairy herds when farmers were given information, and were then involved in formulating farm-specific lameness control plans rather than implementing broad pre-defined control measures (Main et al., 2012). Similarly, the incidence of mastitis decreased by one-third in Swiss dairy farms when the farmers were integrated in the development of measures for prevention and treatment of mastitis (Ivenleyer, 2008). Both dissemination of knowledge and integration of farmers in the development and implementation of such action plans have been shown to be important in successful interventions (Whay and Main, 2015).

Animal welfare programs to improve cow comfort, health and cleanliness have been implemented in large dairy herds in Canada and Australia, where cows were kept in free stalls and tie stalls (Tremetsberger et al., 2015; Bouffard et al., 2017). In smallholder dairy farms in Kenya, cows are typically kept in zero-grazing units, and little research has been reported on attempts to improve the health and welfare of cows by dissemination of knowledge using top-down or farmer integration approaches. The present randomized controlled trial aimed to evaluate: 1) the compliance rate of farm-specific cow comfort changes recommended to smallholder dairy farmers; 
and 2) how the recommendations and the farmers' compliance affected stall cleanliness, cow cleanliness and daily lying time of cows in smallholder dairy farms.

\section{Materials and Methods}

\section{Ethical approval}

The study was approved by the Research Ethics Board and the Animal Care Committee of the University of Prince Edward Island, Canada, the Naari Dairy Farmers Co-operative Society, Kenya and Farmers Helping Farmers, a partnering non-governmental organization based in Prince Edward Island, Canada.

\section{Study design and sampling method}

The study was carried out in the Naari area of Meru County, Kenya, which is a high potential area receiving over $1,600 \mathrm{~mm}$ of rainfall per year, with soils favourable for farming crops and rearing livestock intensively, and therefore small holder dairy farming has been widely practiced in this area for decades. The study was a randomized controlled trial with participating farms being classified as intervention or control farms. The list of 500 active farmers in the Naari Dairy Farmers Co-operative Society (NDFCS) was used as the initial sampling frame.

An initial simple random sample of 200 farms was selected using computer generated random numbers. Of these 200 farms, the following inclusion criteria were used to further narrow the sampling frame of farms for this controlled trial: 1) farms with zero-grazing units; 2) a maximum of four cows per farm; and 3) at least one milking cow. A total of 100 farms met these inclusion criteria with 80 farms randomly assigned to the intervention group and 20 farms randomly assigned to the control group. The uneven distribution of the intervention and control farms was because some of the intervention group farms were expected to have poor/no compliance. Four visits were made to the two groups of farms and the time between the visits was similar for both groups.

\section{Study groups}

On the first visit, the study was described to the farmer and a general survey on cow welfare on the farm was carried out, including administration of a pre-intervention questionnaire on welfare management. Data loggers (Onset HOBO, MacArthur Blvd, Bourne, MA) were attached on the inside of the left upper hind leg just below the hock of milking cows to determine their lying behaviour pre-intervention and removed three days later on the second visit. Additionally, practical changes related to the stall design and management practices were recommended to each farm in the intervention group on the second visit after explaining the reasons for the changes, and discussing the practicalities of the changes. On the third visit approximately a month later, a postintervention questionnaire was administered and the cow welfare assessment was repeated to 
determine whether the recommended changes had been made (compliance) and, if so, how well the farmers had implemented the changes. The data loggers were attached on milking cows to determine their lying behaviour post-intervention. The fourth visit was carried out three days later to remove the data loggers, and to help the farmers implement any changes that had not been completed.

Farms in the control group did not receive cow comfort recommendations during the second visit, but all other activities undertaken on the intervention farms were also carried out on these farms. On the fourth visit, cow comfort changes similar to those recommended on the intervention farms were implemented. The schematic representation of this study design is illustrated in Figure 1.

\section{Data collection}

Lactating cow information collected included: cow identification, age (years), weight (kg-based on a heart girth tape), height $(\mathrm{cm})$, breed (exotic or indigenous) and body condition score using the 5-score chart (Wildman et al., 1982). The typical 5-point lameness status (Sprecher et al., 1997) was collapsed to a 3-point scale (absent, mild or severe) based on the following modification: $1^{\text {st }}$ and $2^{\text {nd }}$ points were combined to form category 1 (absent); $3^{\text {rd }}$ and $4^{\text {th }}$ points were combined to form a category 2 (mild) and the $5^{\text {th }}$ score point was classified as category 3 (severe). The presence or absence of neck, carpal and hock lesions on the cows was determined by physical examinations of the cows.

For stall assessments, various characteristics were categorized according to their appropriateness, based on recommendations associated with the cow's estimated weight (appropriate if within $\pm 10 \%$ of the recommendation for the estimated weight) (Cook, 2009). The total and body length of each stall for lactating cows was measured and categorized as: 1) insufficient length, 2) adequate length, or 3) too long. The total width was similarly categorized as: 1) insufficient width, 2) adequate width, or 3) too wide, allowing the cow to turn around in the stall. Availability and positioning of the neck rail and brisket board were assessed and categorized as: 1) present but not well-positioned, 2) present and well-positioned, or 3) not present in the stall. The availability and adequacy of lunge space (forward and/or side) and side leg space were classified as: 1) space not available, 2) space available but not adequate and 3) adequate space available.

Based on the parameters noted above, three general categories for the characteristics were defined: 1) insufficient space and/or railings present but in the wrong location, leading to cramped space but good stall cleanliness; 2) appropriate space and/or railing positions, leading to both adequate spacing and cleanliness for good overall comfort; and 3) too much space and railings present, leading to good cow space but poor stall cleanliness. Therefore the middle category was considered the optimal category for these characteristics 
The type of floor was recorded as: 1) dirt, 2) concrete or wooden, or 3) other, while the floor flatness was categorized as: 1) flat ( $<5 \%$ of the floor uneven), or 2 ) lumpy ( $\geq 5 \%$ of the floor uneven). The type of bedding available was categorized as: 1) sawdust, 2) wood shavings, 3) crop waste, or 4) other. The knee impact test (from a crouched position on your feet, tipping forward so your knees contact the floor surface) was used to determine how soft the stall surface was, and was categorized into three possible levels: normal, marginal and hard. If the floor was soft and did not cause any level of discomfort on the knees, the floor was categorized as normal which indicated a passing grade on the knee impact test. If the floor was somewhat uncomfortable on the knees, such as a cement floor with a modest amount of bedding or a dirt floor that was compacted, then it was classified as marginal. If the floor caused extreme discomfort on the knees on impact, the floor was classified as hard and this indicated failure of the knee impact test. The degree of wetness on the floor surface was assessed using the knee wetness test, which was categorized as normal if the knee was completely dry after about 10-15 seconds of knee contact on the floor, marginal if the knee had some noticeable moisture, and wet if the knee was completely wet after the contact with the floor. The knee wetness and impact tests have been used elsewhere to assess floor conditions for cattle (McFarland, 1991). The adequacy of the roof (yes or no) was determined based on a visual assessment of the roof, confirming that the roof was adequately covering the entire length of the stall, plus an extra $30 \mathrm{~cm}$ at the udder end, with a roof that was not allowing water to enter the stall because of roof holes. Adequate drainage of the stall (yes or no) was judged by determining whether or not water could flow along the ground from outside into the stall by gravity.

The condition of the alley was categorized based on the amount of manure at the time of assessment, with three possible categories: 1) clean (no manure), 2) fairly clean (small amounts of manure - can easily walk to avoid manure), and 3) muddy (a large amount of manure on the alley - cannot avoid walking in manure). The stall, udder and hind leg cleanliness scores were assessed using a 5-score system (Reneau et al., 2005) from 1 (very clean) to 5 (very dirty).

Farm-level parameters acquired using a face-to-face questionnaire included: number of milking cows in the farm; frequency of hoof trimming; stall manure removal frequency; use of bedding on lying surfaces; frequency of adding new bedding in the stalls; frequency of cleaning the alley; and abnormal behaviours of cows, such as perching, standing idle in the stall, standing backwards in the stall, and lying in places other than the stall.

In the intervention group, farm-specific recommendations for cow comfort changes were made based on a maximum of 12 parameters (Table 1). The recommended changes were given orally and in written form, using the language of choice of the farmer (English, Swahili, Kimeru).

Compliance was assessed for each type of comfort parameter recommended for change on the intervention farms by the investigator using a post-intervention questionnaire. For each comfort 
parameter recommended, there were three possible outcomes: 0) no compliance (not done), 1) partial compliance (change attempted but not completed and/or change done incorrectly), and 2) total compliance (change carried out completely and correctly). Additionally, information on costs, challenges and improved knowledge on cow comfort was acquired from farmers in the intervention group through a face-to-face interview and questionnaire.

The data loggers that recorded $\mathrm{x}-, \mathrm{y}$ - and $\mathrm{z}$ - axis acceleration were used to record the lying time of cows. The specifications, calibration and operation of the data loggers was carried out as per the manufacturer's manual (HOBO Pendant G Acceleration Data Logger (UA-004-64) Manual).

\section{Data management and statistical analysis}

Data were entered, cleaned and coded using Microsoft Excel® 2013 (Microsoft, Sacramento, California, USA) and analyzed using Stata 14.2® (StataCorp, College Station, Texas, USA). Daily lying time of each cow was calculated by standardizing the lying time for 72 hours then dividing by three.

Daily cow lying times and cleanliness scores (stall, udder and upper hind legs) were described using medians and ranges, and their differences within and between groups over the assessment time were assessed using the Kruskal-Wallis rank test. Proportions of clean $(\leq 2.5)$ and dirty $(>2.5)$ stalls, udders and upper hind legs were also used to describe cleanliness scores in the groups. To fulfill the normality assumption of parametric statistical tests, lying time was transformed using the natural $\log$.

The compliance variables (for each of the recommended changes) were collapsed into two groups: 0 ) no compliance and 1) compliance (partial or full) due to the fact that partial compliance occurred in the observed data. Description of farmers' compliance, and their feedback on the recommendations, were determined using simple proportions. For determining factors associated with compliance, a new comfort parameter variable was generated that combined the 12 comfort parameters into 4 categories with similar stall characteristics: 1) "stall design" (lunge space, side leg space, neck rail and brisket board); 2) "stall size" (stall length and stall width); 3) "floor characteristics" (floor softness and floor flatness); and 4) "other" ( roof adequacy, drainage of surface water, cleanliness of the alley and sharps fixes). The scores for each of the categories of these combined comfort parameters were determined by the aggregate scores of the respective comfort parameters of which each was comprised.

Mixed univariable logistic regression analyses with farm random effects were used to determine unconditional associations of exposure variables such as type of recommendations given (minor or major), recipient of the recommendations (female principal farmer, male principal farmer or farm-hand) and type of combined comfort parameter identified for change (stall design, stall size, floor characteristics or other) were associated with farmers' compliance which was the outcome 
of interest. Then, a mixed multivariable logistic regression model was fit with the eligible factors ( $p<0.25$ in the univariable analyses) to determine their association with compliance on all the 62 intervention farms while controlling for clustering at the farm level. A second mixed multivariable logistic regression model with farm random effects, compliance as the outcome of interest and the same exposure factors was developed that included only those farms that had attempted at least one of the given recommendations $(n=46)$. Pearson correlation coefficients were used to identify correlated predictors and to aid the process of model-building.

To evaluate the interaction effects of the intervention and visits to all of the 73 study farms, irrespective of compliance, on the daily lying time and cleanliness scores (stall and cow), univariable and multivariable mixed linear and logistic regression models with farm random effects were used, respectively. Marginal analyses and interaction plots were used to illustrate interaction effects.

A final set of statistical univariable and multivariable logistic and linear regression analyses on the lying time and cleanliness outcomes were conducted to account for varying compliance of farmers to the recommendations. To evaluate the effects of the intervention, visit and compliance on the outcomes, a variable was generated which had three categories: 0) the comfort parameter needed no change and therefore no recommendation was given; 1) the comfort parameter needed a change, a recommendation was given, and the farmer partially or completely complied; and 2) the comfort parameter needed a change, a recommendation was given, but the farmer did not comply at all.

Multivariable mixed linear and logistic regression models were used to determine the effects of groups, visits (pre-and post-intervention), and compliance to implement the needed changes, and their interaction, on lying time and cleanliness scores (stall, udder and upper hind leg) respectively, for cows on the 62 intervention farms and for cows on the 46 intervention farms that implemented at least one of the recommended changes.

Standardized residuals were used to evaluate the assumptions of normality, linearity and homoscedasticity for the linear regression models. In addition outliers were identified, and leverage, Cooks distance, and delta-beta values were used to identify influential observations.

Intra-class correlation values were used to assess the random effects of farms on the variability observed in the outcomes post-intervention.

\section{Results}

A total of 73 farms with 106 milking cows remained in the trial to the end of the study; 62 farms with 90 milking cows in the intervention group and 11 farms with 16 milking cows in the control group. The 18 intervention farms and 9 control farms were lost from the trial before the third visit because they no longer had a lactating cow (due to death, culling or drying off), or they relocated 
to another region of the country, but none of these reasons were deemed to be related to the study objectives.

The mean milk production per cow per day was $6.6 \pm 3.3$ litres pre-intervention. The mean daily lying time pre- and post-intervention was $10.9 \pm 2.2$ and $11.5 \pm 2.3$ hours, respectively.

Mean stall, udder and upper leg cleanliness scores pre-intervention were $2.4 \pm 1.0,1.9 \pm 0.7$, and $2.5 \pm 1.1$, respectively. The mean daily lying time in the intervention and control groups preintervention was $11.06 \pm 2.2$ and $10.27 \pm 2.1$ hours, respectively, and $11.58 \pm 2.3$ and $10.92 \pm 1.9$ hours respectively, post-intervention (Table 2).

Before cow comfort recommendations were made, milking cows in all the farms were non-lame, and only one mild case of lameness was observed post-intervention. Neck, carpal and hock lesions were present in $15 \%, 13 \%$ and $15 \%$ of the cows. Due to the short time frame between the intervention and post-intervention assessment, these lesions were not expected to change much and therefore were assessed only once for descriptive purposes.

\section{Compliance assessment}

The number of recommendations given to each intervention farm ranged from 1 to 10 , and compliance was evaluated after an average (s.d) of 39 \pm 7 days.

A total of 324 cow comfort changes were recommended to the 62 farms, with $79 \%$ of the changes being major. Of the 62 intervention farms completing the trial, the largest percentage of farms received a recommendation to change the lunge space $(85.5 \%)$ and neck rail availability and /or positioning (83.9\%), while the lowest proportions related to the roof $(11.3 \%)$, total stall length (11.3\%), removal of sharps $(11.3 \%)$ and surface water drainage $(9.7 \%)$ (Table 3$)$.

Of the 324 recommendations made to farmers, 204 (63.0\%) were implemented. Over $70 \%$ of the farmers implemented changes related to neck rail, brisket board, softening and flattening of the

lying surface (Table 3). Lengthening stalls and addressing surface water drainage were infrequent recommendations but they also had the lowest compliance at around $15 \%$. The proportion of the farmers that implemented at least one of the recommended changes was $74 \%(46 / 62)$. The recommendations given could be implemented using readily accessible and available resources, such as the recommended use of timber from their farms in order to improve stall design, dirt from their farms to improve on floor characteristics, and crop-waste from their farms as bedding.

On 26 farms (42\%), all of the recommended changes were implemented partially or fully. Most changes $(>50 \%)$ were made on $22 \%(14 / 62)$ of the farms, some changes $(<50 \%)$ were made on $10 \%(6 / 62)$ of the farms, while no changes were made on $26 \%(16 / 62)$ of the farms. Therefore, 46 of the 73 farms finishing the trial were effectively intervention farms, while 27 of the 73 farms 
were effectively control farms, which included the 11 farms that received no intervention and the 16 farms that received the intervention but implemented none of the intervention recommendations.

Nearly half (47\%) of the 46 farms that implemented changes started within 24 hours of the recommendations being made, while $18 \%$ and $6 \%$ of the farms started implementation within the first week and later than the first week post-recommendation, respectively. Recipients of cow comfort recommendations were female principal farmers in 50\% (31/62) of the farms, male principal farmers in $42 \%(26 / 62)$ of the farms and farm-hands in $8 \%(2 / 62)$ of the farms. Postintervention, the 26\% (16/62) gave various reasons for not implementing the changes recommended including: poor stall stability to make changes, plans to rebuild new stalls, relocation from their homes and lack of direct benefits on implementation. Of the 46 farmers that implemented at least one of the recommended changes, five (11\%) reported that some recommendations, such as total length improvements, were hard to implement, and 96\% (44/46) of farmers felt well-versed in cow comfort (Table 4). Only 15 (33\%) of the 46 compliant farmers incurred costs of implementing changes, and an average cost (s.d.) of Ksh. 344 \pm 222 (CDN\$5) was estimated among the 15 farmers.

Two challenges were observed on 8 farms after cow comfort improvements were attempted including: fighting between cows for preferred stalls and in-ability to lie down in a stall when changes were not done properly.

A mixed multivariable logistic regression model of the 62 intervention farms, with farm as a random effect, determined that type of recommendations, recipient of the recommendations and the type of combined comfort parameter identified for change (categories 1-4) were factors $(p<0.05)$ associated with compliance to implement changes (Table 5; top). Six times higher odds of compliance were observed when major recommendations were given relative to minor recommendations. Changes related to the lying surface (FS and FF) had 3.1 times higher odds of being implemented compared to changes related to stall design (NR, BB, LeS and LuS). The odds of compliance were much lower on farms where the farm-hand received the recommendations in comparison to farms where the female principal farmer received the recommendations. Given that a recommended change for a given comfort parameter was made in a given farm, the probability of another recommended change being implemented on the same farm was $84.4 \%$ (ICC $=0.844$ ).

To assess factors associated with compliance in the intervention farms that attempted to implement at least one recommendation ( $\mathrm{n}=46$ farms; i.e. per protocol analysis), a similar multivariable logistic regression model was identified, where type of recommendation given, recipient of the recommendations and the type of combined comfort parameter identified for change (categories 1-4) were again in the final model (Table 5; bottom). In this model, the odds of compliance were lower on farms where the male principal farmer or the farm-hand received the recommendations 
in comparison to farms where the female principal farmer received the recommendations. Also, if farmers had at least one recommendation that they considered was hard for them to implement, the odds of compliance in these farms was significantly lower compared to farms where no recommendations were considered hard. Farm random effects were negligible in this final model, and the final model fit the data well.

\section{Differences in outcomes between groups, irrespective of compliance}

Based on the Kruskal-Wallis rank test, the median lying times were not significantly different between the intervention $(n=62)$ and control groups $(n=11)$ pre- and post-intervention irrespective of compliance (Table 6). The stall cleanliness score was significantly lower post-intervention than pre-intervention $(\mathrm{p}=0.0001)$ in the intervention farms but remained similar on control farms $(\mathrm{p}=0.122)$. The udder and leg cleanliness scores also decreased significantly in the intervention group cows post-intervention but remained similar in control farms (Table 6).

After categorization of stall and cow cleanliness into dirty ( $>2.5)$ and clean, in the 62 intervention farms, the proportion of stalls that were categorized as dirty pre-intervention was 35\% (31/88), which declined significantly $(\mathrm{p}=0.0002)$ to $11 \%(10 / 88)$ post-intervention. In the control farms, the proportion of stalls categorized as dirty remained relatively similar pre-intervention $(5 / 15$; $33 \%)$ to post-intervention $(4 / 15 ; 27 \%)$. Among the intervention farms pre-intervention, $50 \%$ of the cows $(45 / 90)$ had their upper hind legs categorized as dirty (>2.5), while $31 \%$ of the 16 cows on control farms had upper hind legs categorized as dirty. Post-intervention, the proportion of cows with upper hind legs categorized as dirty was similar in both groups (intervention $=38 \%$ and control $=37 \%$ ). None of these differences, by intervention group, were statistically significantly different.

Controlling for the clustering of pre- and post-intervention assessments within cows, the multivariable mixed logistic regression models with farm random effects indicated no significant interaction effects between groups and visits on the outcomes $(p>0.05)$. However, one interaction plot illustrated a particularly interesting improvement in stall cleanliness that was greater in the treatment group than the control group post-intervention (Figure 2).

\section{Differences in outcomes between groups, considering compliance}

The intervention group was a mixture of farms that complied with the recommendations and farms that did not comply with the recommendations, biasing the results of the previous section. Therefore, additional statistical analyses were conducted comparing the 71 cows on the 46 farms that complied with at least one of the recommendations versus the 35 cows in the 27 remaining 
farms, which was a combination of the 11 control farms and 16 intervention farms where farmers made no effort to comply to the recommendations.

Controlling for the clustering of pre- and post-intervention assessments within cows, the multivariable mixed logistic regression models with farm random effects indicated no significant interaction effects between these altered groups and visits on the outcomes (all $p>0.05$ ). However, an interaction plot derived from the multivariable mixed logistic regression model indicated that stall cleanliness improved on farms that did not have a neck rail, were recommended to have one, and the farmer placed a neck rail. Stall cleanliness had only a modest improvement on farms that had a poorly positioned neck rail, and recommendations were given to better position it, but the recommendations were not implemented (Figure 3).

On farms that made at least one of the recommended changes $(n=46)$, an interaction plot derived from a similar mixed linear regression model indicated that failure to implement the proposed changes on forward and/or side lunge space in the stalls led to a decline in the log of lying time of the cows from pre- to post-intervention assessments, relative to the other two interaction categories (Figure 4).

\section{Discussion}

This is the first study to assess farmers' compliance to implementing recommended cow comfort changes on smallholder dairy farms in Kenya. Instead of making the changes for the farmers, the project gave recommendations to farmers to ensure sustainability of the project, where farmers were responsible for carrying out the recommended changes. Hopefully, the farmers would also advise other farmers after the project was completed, thereby improving cow comfort and welfare in smallholder dairy farms regionally, and subsequently improve cow productivity and health.

The overall proportion of farmers who implemented at least one of the recommended changes (74\%) was higher than that reported for Australian dairy herds (57\%) (Tremetsberger et al., 2015). The relatively good acceptance and implementation of recommended changes may be attributed to the integration of farmers in the formulation of improvement measures, which enables the farmers to feel that their opinions are respected in the process, and therefore, they are more likely to accept the changes and implement the changes. In addition, the recommendations given could be implemented using readily accessible and available resources, such as the recommended use of timber from their farms in order to improve stall design, dirt from their farms to improve on floor characteristics, and the use of crop-waste from their farms as bedding. Only 15 of the 46 farms that implemented at least one of the recommended changes incurred costs, which ranged from Ksh.122 to 566 (CDN\$ 1.5 to 7.5). This amount is manageable when considering the estimated monthly income of a smallholder household in Kenya (Ksh.15, 842) as reported by the Food and Agricultural Organization in 2015 (Global Forum On Agricultural Research, 2016). The use of the 
native language of Kimeru when giving the recommended oral and written changes to the farmers may also have contributed to a better response.

We might expect that farmers would be more likely to implement minor changes in comparison to major changes; however, in this study, farmers implemented major changes significantly more often than was the case for minor changes $(\mathrm{OR}=6.28)$. This unexpected finding could be due to the direct proportionality assumption, that a major change in cow comfort parameters would lead to a larger change in cow productivity, and vice versa.

Out of the 12 comfort parameters assessed, recommended changes to improve floor softness and flatness, leg space, lunge space and neck rail availability and positioning were implemented most frequently. Considering that most dairy farmers in Kenya also produce crops (Mugambi et al., 2015), dirt and crop-waste are readily available and accessible, thus they can be added to the dirt floors to flatten and soften the surfaces regularly. Implementation of recommended roof and stall length changes could have been limited by the land area available to extend stalls to due to the small sizes of the farms ( 0.47 hectares) available to smallholder dairy farmers in Kenya (Global Forum On Agricultural Research, 2016), while replacing roofs or covering the holes to prevent water getting into the stall may have been expensive for the farmers thus reducing their compliance. Recommended changes to create or increase leg space and lunge space involved repositioning of side rails that were already in the stall, which meant that farmers incurred no cost at all to make these changes. Also, with the increased forest plantations in rural Kenya, timber is more easily accessible and commonly used as a building material for stalls and other structures (Rudel, 2009), which would partly explain the higher likelihood of implementing neck rail changes compared to the roof changes.

On farms that implemented at least one of the recommended changes, compliance was lower when a male principal farmer or farm-hands received the recommendations compared to when the principal farmer was female. This could possibly be due to the more active role of women in smallholder dairy farms, as reported in an earlier study that women carried out $70 \%$ of all the activities in the farm (Nyongesa et al., 2016). As expected, when farmers deemed that recommendations would be hard to implement, the level of compliance for the specific comfort parameters was reduced. The complete non-compliance in $26 \%(16 / 62)$ of the intervention farms was not unexpected because some farms were less motivated to make changes that were welfare related with no clear and obvious financial benefits.

The mean daily lying time for the 90 cows on the 62 intervention farms, pre- and post-intervention, were 10.9 and 11.5 hours, respectively, which was not a significant improvement. Our findings contrast those made by Richards (2017) who reported a significant improvement $(\mathrm{p}<0.001)$ in mean daily lying time from 9.0 to 10.2 hours at baseline and one month post-intervention, respectively, for cows kept in smallholder dairy farms in Mukurweini, in Kenya. The Mukurweini 
study cows had a lower mean lying time at the baseline than our study, providing more opportunity for significant improvement, and the cow comfort changes identified were implemented by the investigator, whereas in the present study, the changes identified were recommended for farmers to implement.

Improvement of stall design and stall management practices has been found to improve stall cleanliness and cow cleanliness in earlier studies (Tremetsberger et al., 2015; Bouffard et al., 2017; Richards, 2017) and in the present study. When farmers made recommended changes on stalls, such as neck rail placement and positioning, stall cleanliness was improved (Figure 2). The similarity between the udder cleanliness in the intervention group cows pre- and post-intervention could be attributed to the relatively low udder scores (clean) before any recommendations were given (Table 5), which did not leave a lot of opportunity for improvement.

The trend of declining daily lying time among the intervention farms that did not implement recommended changes on forward and/or side lunge space (Figure 3) makes biological sense. Cows find it difficult to stand up without adequate lunge space, which hinders their willingness to lie down and their lying patterns in cow stalls (Ceballos, 2003).

There are a number of likely reasons for the failure to demonstrate significant differences in some of the outcomes through the interventions. The smallholder dairy farmers in the study area are part of a closely knit community, and knowledge is often shared widely. This sharing may have led to un-avoidable knowledge transfer regarding the recommendations being passed on to the control farms from the intervention farms, which may have led to improvements on the control farms. Furthermore, there were higher than expected baseline assessments associated with a number of the outcomes, leading to reduced opportunity for improvement. Finally, the sample size was initially limited to 100 farms for logistic reasons, with only 73 farms remaining involved by the end of the trial. Future studies should endeavour to find larger populations of farmers with substantial cow comfort problems that have similar characteristics but are geographically separated, to reduce the potential for "contamination" of the control group.

\section{Conclusions and Recommendations}

Overall, giving smallholder dairy farmers recommendations to improve cow comfort did improve the stall cleanliness and upper leg cleanliness of cows in the farms, and led to a modest gain in daily lying times. The smallholder dairy farmers' compliance when implementing recommended cow comfort changes was good, with $74 \%$ of the farmers making at least one change and overall $63 \%$ of the recommendations being implemented. The compliance was higher when major changes were recommended in comparison to minor changes. Importantly, female principal farmers had a higher compliance to implement recommended cow comfort changes than male principal farmers or farm-hands. Some stall features such as neck rail, brisket board, lunge space and leg space were 
more likely to be implemented in comparison to others (e.g., roof, stall length and sharps fix). In the short term, some outcomes, such as stall, udder and upper leg hygiene scores, improved when recommended cow comfort changes were implemented. Appropriate placement of a neck rail in the stalls improved stall cleanliness scores (lower scores). On farms that implemented at least one of the recommended changes, stall lunge space improvements increased lying time of cows by 1 hour. Giving farm-specific cow comfort recommendations to smallholder dairy farmers in Kenya and providing the farmers with a participatory role in the formulation and implementation of improvement measures resulted in good acceptance, with a high degree of compliance and subsequent improvement of cow welfare.

In future, a longitudinal study on the long-term effects of farmers implementing recommended cow comfort changes on dairy farms in Kenya is recommended, including 1) outcomes such as lying patterns, milk production and mastitis prevention; and 2) the profitability and sustainability of giving recommendations to farmers instead of making changes for them.

\section{Acknowledgements}

We are grateful to the primary funding program for this research, the Canadian Queen Elizabeth II Diamond Jubilee Scholarships (QES) which are managed through a unique partnership of Universities Canada, the Rideau Hall Foundation (RHF), Community Foundations of Canada (CFC) and Canadian universities. This program is made possible with financial support from the Government of Canada, provincial governments and the private sector. We also acknowledge the large contribution made by volunteers and staff of Farmers Helping Farmers, a non-governmental organization - their existing relationships and agricultural efforts and inputs provided a strong foundation for the work and the entry point to the Naari community. We acknowledge the leadership and members of the Naari Dairy Farmers Cooperative Society in Meru for their cooperation in the study. We appreciate the help offered by Shauna Richards with the analysis of the accelerometer data, and Ren Chamberlain and Julia Kenny for their help in data collection in the field. 


\section{References}

Bell, N. J., M. J. Bell, T. G. Knowles, H. R. Whay, D. J. Main and A. J. F. Webster. 2009. The development, implementation and testing of a lameness control programme based on HACCP principles and designed for heifers on dairy farms. The Veterinary Journal. 180:178-188.

Bernardi, F., J. Fregonesi, C. Winckler, D. M. Veira, von Keyserlingk, M A G and D. M. Weary. 2009. The stall-design paradox: Neck rails increase lameness but improve udder and stall hygiene. J. Dairy Sci. 92:3074-3080.

Bickert, W. G. 2000. Freestall design. Natural Resource, Agriculture and Engineering Service Publications Nraes. 205-213.

Bouffard, V., A. M. de Passille, J. Rushen, E. Vasseur, C. G. R. Nash, D. B. Haley and D. Pellerin. 2017. Research: Effect of following recommendations for tiestall configuration on neck and leg lesions, lameness, cleanliness, and lying time in dairy cows. J. Dairy Sci. 100:2935-2943.

Ceballos, A. 2003. How cows lie down : A 3-D kinematic evaluation of the lying down behaviour of holstein dairy cows.

Cook, N. B., T. B. Bennett and K. V. Nordlund. 2005. Monitoring indices of cow comfort in free-stall-housed dairy herds. J. Dairy Sci. 88:3876-3885.

Cook, N. B. 2009. Free-stall design for maximum cow comfort. WCDS Adv. Dairy Technol. 21:255-268.

DeVries, T. J., M. G. Aarnoudse, H. W. Barkema, K. E. Leslie and von Keyserlingk, M A G. 2012. Associations of dairy cow behavior, barn hygiene, cow hygiene, and risk of elevated somatic cell count. J. Dairy Sci. 95:5730-5739.

Fregonesi, J. A., D. M. Veira, von Keyserlingk, M A G and D. M. Weary. 2007. Effects of bedding quality on lying behavior of dairy cows. J. Dairy Sci. 90:5468-5472.

Global Forum On Agricultural Research. 2016. Improving the economic lives of smallholder farmers.

Ivenleyer, S. 2008. Effects of a two-year dairy herd health management programme on udder health, use of antibiotics and longevity. Schweiz. Arch. Tierheilkd. 150:499-505.

Main, D. C. J., K. A. Leach, Z. E. Barker, A. K. Sedgwick, C. M. Maggs, N. J. Bell and H. R. Whay. 2012. Evaluating an intervention to reduce lameness in dairy cattle. J. Dairy Sci. 95:2946-2954. 
McFarland, D. F. 1991. Experiences with free stall design in pennsylvania. Paper - American Society of Agricultural Engineers. 17.

Mugambi, D. K., M. Mwangi, S. K. Wambugu and A. M. M. Gitunu. 2015. Assessment of performance of smallholder dairy farms in kenya: An econometric approach. Journal of Applied Biosciences. 85:7891-7899.

Norring, M., E. Manninen, H. Saloniemi, A. M. de Passille, J. Rushen and L. Munksgaard. 2008. Effects of sand and straw bedding on the lying behavior, cleanliness, and hoof and hock injuries of dairy cows. J. Dairy Sci. 91:570-576.

Nyongesa, D., M. K. Mwirigi, D. Yongo and S. Makokha. 2016. Gender-concerns: Do they matter in smallholder dairy groups in kenya? Int. J. Agric. Resour., Governance Ecol. 12:117.

Reneau, J. K., A. J. Seykora, B. J. Heins, M. I. Endres, R. J. Farnsworth and R. F. Bey. 2005. Association between hygiene scores and somatic cell scores in dairy cattle. J. Am. Vet. Med. Assoc. 227:1297-1301.

Richards, S.M. 2017. Productivity and welfare of cpws in smallholder dairy farms in Kenya, $\mathrm{PhD}$ Dissertation, University of Prince Edward Island, Charlottetown.

Rollin, B. E. 2004. Animal agriculture and emerging social ethics for animals. Large Animal.Proceedings of the North American Veterinary Conference, Volume 18, Orlando, Florida, USA, 17-21 January 2004.

Rudel, T. K. 2009. Tree farms: Driving forces and regional patterns in the global expansion of forest plantations. Land use Policy. 26:545-550.

Rushen, J., A. Butterworth and J. C. Swanson. 2011. Animal behavior and well-being symposium: Farm animal welfare assurance: Science and application. J. Anim. Sci. 1219.

Sprecher, D. J., D. E. Hostetler and J. B. Kaneene. 1997. A lameness scoring system that uses posture and gait to predict dairy cattle reproductive performance. Theriogenology. 1179.

Tremetsberger, L., C. Leeb and C. Winckler. 2015. Animal health and welfare planning improves udder health and cleanliness but not leg health in austrian dairy herds. J. Dairy Sci. 98:6801-6811.

Tucker, C. B., D. M. Weary and D. Fraser. 2005. Influence of neck-rail placement on free-stall preference, use, and cleanliness. J. Dairy Sci. 88:2730-2737.

Tucker, C. B., D. M. Weary and D. Fraser. 2004. Free-stall dimensions: Effects on preference and stall usage. J. Dairy Sci. 87:1208-1216. 
Tucker, C. B., G. Zdanowicz and D. M. Weary. 2006. Brisket boards reduce freestall use. J. Dairy Sci. 89:2603-2607.

Vasseur, E., J. Gibbons, J. Rushen, D. Pellerin, E. Pajor, D. Lefebvre and A. M. de Passille. 2015. An assessment tool to help producers improve cow comfort on their farms. J. Dairy Sci. 98:698-708.

Whay, H. R. and D. C. J. Main. 2015. Improving animal care and welfare: Practical approaches for achieving change. Improving Animal Welfare: A Practical Approach.

Wildman, E. E., G. M. Jones, P. E. Wagner, R. L. Boman, H. F. Troutt J. and T. N. Lesch. 1982. A dairy cow body condition scoring system and its relationship to selected production characteristics. J. Dairy Sci. 65:495-501. 
Table 1: Examples of minor and major stall changes ${ }^{1}$ recommended to smallholder dairy farms in Kenya 2017

\begin{tabular}{|c|c|c|}
\hline $\begin{array}{l}\text { Comfort } \\
\text { parameter }\end{array}$ & Example of minor change & Example of major change \\
\hline Roof (RF) & Patch holes on roof & Replace section of the roof \\
\hline $\begin{array}{l}\text { Drainage of } \\
\text { surface water } \\
(\mathrm{DSW})\end{array}$ & $\begin{array}{l}\text { Improve on an existing drainage } \\
\text { system, such as adding to a section } \\
\text { of a berm }\end{array}$ & $\begin{array}{l}\text { Dig a trench outside the stall to } \\
\text { facilitate and improve drainage } \\
\text { around the stall }\end{array}$ \\
\hline $\begin{array}{l}\text { Floor softness } \\
\text { (FS) }\end{array}$ & $\begin{array}{l}\text { Add bedding to already bedded } \\
\text { surface }\end{array}$ & $\begin{array}{l}\text { Avail bedding to a non-bedded } \\
\text { surface }\end{array}$ \\
\hline Floor flatness (FF) & $\begin{array}{l}\text { Level a small portion of floor } \\
(<25 \%) \text { surface }\end{array}$ & $\begin{array}{l}\text { Level a large portion }(\geq 25 \%) \text { or the } \\
\text { entire floor surface }\end{array}$ \\
\hline Stall width (SW) & $\begin{array}{l}\text { Move a side board from one side of } \\
\text { the vertical post to the other }\end{array}$ & $\begin{array}{l}\text { Add new side boards to reduce } \\
\text { width }\end{array}$ \\
\hline Stall length (SL) & $\begin{array}{l}\text { Remove } 1-2 \text { front boards to } \\
\text { increase length }\end{array}$ & $\begin{array}{l}\text { Remove all front boards to increase } \\
\text { length }\end{array}$ \\
\hline Leg space (LeS) & $\begin{array}{l}\text { Remove the lowest sideboard on } \\
\text { one side of the stall }\end{array}$ & $\begin{array}{l}\text { Remove the lowest side boards on } \\
\text { both sides of the stall }\end{array}$ \\
\hline $\begin{array}{l}\text { Lunge space } \\
(\mathrm{LuS})\end{array}$ & $\begin{array}{l}\text { Move a sideboard lower or higher } \\
\text { to create enough side lunge space }\end{array}$ & $\begin{array}{l}\text { Move or remove multiple boards } \\
\text { on the front or side to create } \\
\text { enough lunge space }\end{array}$ \\
\hline Neck rail (NR) & Repositioning an existing neck rail & $\begin{array}{l}\text { Placing and positioning a new neck } \\
\text { rail }\end{array}$ \\
\hline $\begin{array}{l}\text { Brisket board } \\
\text { (BB) }\end{array}$ & $\begin{array}{l}\text { Repositioning an existing brisket } \\
\text { board }\end{array}$ & $\begin{array}{l}\text { Placing and positioning a new } \\
\text { brisket board }\end{array}$ \\
\hline Alley clean (AC) & $\begin{array}{l}\text { Clean an alley with 2-6 days } \\
\text { manure }\end{array}$ & $\begin{array}{l}\text { Clean an alley with a least a } \\
\text { week's manure }\end{array}$ \\
\hline Sharps fix (SF) & Bend and/or remove 1-3 sharps & Bend and/or remove $>3$ sharps \\
\hline
\end{tabular}


Table 2: Mean $( \pm \mathrm{SD})$ of cow lying time, stall cleanliness and cows' own cleanliness scores observed in 73 smallholder farms in a cow comfort trial in Kenya

\begin{tabular}{lllll}
\hline & \multicolumn{2}{c}{ Pre-intervention } & \multicolumn{2}{c}{ Post-intervention } \\
\hline Outcome & $\begin{array}{l}\text { Intervention } \\
\text { group }^{*}\end{array}$ & $\begin{array}{l}\text { Control } \\
\text { group }^{* *}\end{array}$ & $\begin{array}{l}\text { Intervention } \\
\text { group }^{*}\end{array}$ & $\begin{array}{l}\text { Control } \\
\text { group }\end{array}$ \\
Lying time (hrs) & $11.06 \pm 2.2$ & $10.27 \pm 2.1$ & $11.58 \pm 2.3$ & $10.92 \pm 1.9$ \\
Stall cleanliness score $(1-5)$ & $2.4 \pm 0.9$ & $2.4 \pm 1.0$ & $1.7 \pm 0.8$ & $1.9 \pm 1.1$ \\
Udder cleanliness score (1-5) & $1.9 \pm 0.7$ & $1.8 \pm 0.6$ & $1.7 \pm 0.7$ & $1.5 \pm 0.6$ \\
Leg cleanliness score (1-5) & $2.6 \pm 1.1$ & $2.0 \pm 1.1$ & $2.3 \pm 0.9$ & $2.2 \pm 1.0$ \\
\hline
\end{tabular}

$*_{\mathrm{n}}=90$ cows on 62 farms, $* * \mathrm{n}=16$ cows on 11 farms

Table 3: Number of farms given recommendations for each of the 12 possible comfort parameters and the number (and percentage, based on the 62 intervention farms finishing the trial) that implemented the changes in Meru, Kenya, in 2017.

\begin{tabular}{lllll}
\hline $\begin{array}{l}\text { Comfort } \\
\text { parameter }\end{array}$ & $\begin{array}{l}\text { \# of farms given } \\
\text { recommendations }\end{array}$ & $\begin{array}{l}\text { \% of farms given } \\
\text { recommendations }\end{array}$ & $\begin{array}{l}\text { \# of farms } \\
\text { complying }\end{array}$ & $\begin{array}{l}\text { \% of farms } \\
\text { complying }\end{array}$ \\
\hline Roof & 7 & 11.3 & 2 & 28.6 \\
Surface water & 6 & 9.7 & 1 & 16.7 \\
Floor softness & 45 & 72.6 & 32 & 71.1 \\
Floor flatness & 33 & 53.2 & 24 & 72.7 \\
Stall width & 29 & 46.8 & 16 & 55.2 \\
Stall length & 7 & 11.3 & 1 & 14.3 \\
Leg space & 22 & 35.5 & 16 & 72.7 \\
Lunge space & 53 & 85.5 & 37 & 69.8 \\
Neck rail & 52 & 83.9 & 38 & 73.1 \\
Brisket board & 48 & 77.4 & 27 & 56.3 \\
Alley condition & 15 & 24.2 & 6 & 40.0 \\
Sharps fix & 7 & 11.3 & 4 & 57.1 \\
\hline
\end{tabular}


Table 4: Descriptive statistics of feedback regarding the stall recommendations given by $\mathbf{4 6}$ smallholder farmers that made at least one cow comfort change in response to recommendations in Kenya in 2017

\begin{tabular}{|c|c|c|c|}
\hline Factor & $\begin{array}{l}\text { No. }(\%) \text { of } \\
\text { farmers that } \\
\text { responded Yes }\end{array}$ & $\begin{array}{l}95 \% \text { CI of } \\
\text { Yes Percent }\end{array}$ & Reasons and/or examples \\
\hline $\begin{array}{l}\text { Hard recommendations } \\
\text { encountered }\end{array}$ & $5(11 \%)$ & $(3.6,23.6)$ & $\begin{array}{l}\text { Small parcels of land were } \\
\text { restrictive of increasing stall } \\
\text { length }\end{array}$ \\
\hline $\begin{array}{l}\text { Cost incurred during } \\
\text { implementation }\end{array}$ & $15(33 \%)$ & $(19.5,48.1)$ & $\begin{array}{l}\text { Did not have trees on the farm } \\
\text { and had to outsource timber } \\
\text { Other inputs such as nails }\end{array}$ \\
\hline $\begin{array}{l}\text { Well versed with cow } \\
\text { comfort post-intervention }\end{array}$ & $44(96 \%)$ & $(85.2,99.5)$ & $\begin{array}{l}\text { Making the changes } \\
\text { themselves led to better } \\
\text { understanding and less } \\
\text { likelihood of forgetting }\end{array}$ \\
\hline $\begin{array}{l}\text { Advised others on cow } \\
\text { comfort as requested by the } \\
\text { investigator }\end{array}$ & $20(44 \%)$ & $(28.9,58.9)$ & $\begin{array}{l}\text { Wanted to help their family } \\
\text { and friends } \\
\text { Opportunity to practice what } \\
\text { they learnt }\end{array}$ \\
\hline $\begin{array}{l}\text { Challenges encountered } \\
\text { after implementing } \\
\text { recommended changes }\end{array}$ & $8(17 \%)$ & $(7.8,31.4)$ & $\begin{array}{l}\text { Fighting of cows in adjacent } \\
\text { stalls due to increased side } \\
\text { lunge space } \\
\text { In ability to lie down on the } \\
\text { stalls when the changes were } \\
\text { poorly done, such as neck rail } \\
\text { placement } \\
\text { Cows lying down on the alley } \\
\text { initially when the stalls } \\
\text { appeared different }\end{array}$ \\
\hline
\end{tabular}


Table 5: Multivariable logistic regression models of factors associated with farmers' compliance to implement cow comfort changes recommended in smallholder dairy farms in Kenya in 2017

\begin{tabular}{|c|c|c|c|c|}
\hline Factor & Category & Odds Ratio & {$[95 \mathrm{CI}]$} & P-value \\
\hline \multicolumn{5}{|c|}{$n=62$ intervention farms that completed the trial } \\
\hline \multirow[t]{2}{*}{ Type of recommendations } & Minor & Reference & & \\
\hline & Major & 6.28 & $1.78,22.14$ & 0.004 \\
\hline \multirow{3}{*}{$\begin{array}{l}\text { Recipient of } \\
\text { recommendations }\end{array}$} & Wife & Reference & & $0.046^{*}$ \\
\hline & Husband & 1.78 & $0.24,13.45$ & 0.578 \\
\hline & Farm hand & 0.01 & $0.001,0.34$ & 0.023 \\
\hline \multirow{4}{*}{$\begin{array}{l}\text { Combined comfort } \\
\text { parameters recommended } \\
\text { for change }\end{array}$} & Stall design & Reference & & $0.002 *$ \\
\hline & Stall size & 0.46 & $0.12,1.80$ & 0.263 \\
\hline & Floor characteristics & 3.14 & $1.02,9.70$ & 0.047 \\
\hline & Others & 0.13 & $0.03,0.31$ & 0.004 \\
\hline \multirow{2}{*}{\multicolumn{5}{|c|}{$n=46$ intervention farms that implemented at least one of the recommended changes }} \\
\hline \multirow[t]{2}{*}{ Type of recommendations } & Minor & Reference & & \\
\hline & Major & 3.98 & $1.64,9.65$ & 0.002 \\
\hline \multirow[t]{2}{*}{ Any hard recommendations } & None & Reference & & \\
\hline & At least one & 0.32 & $0.12,0.84$ & 0.021 \\
\hline \multirow{3}{*}{$\begin{array}{l}\text { Recipient of } \\
\text { recommendations }\end{array}$} & Wife & Reference & & $0.023 *$ \\
\hline & Husbal & 0.39 & $0.16,0.95$ & 0.037 \\
\hline & Farm hand & 0.12 & $0.02,0.68$ & 0.016 \\
\hline \multirow{4}{*}{$\begin{array}{l}\text { Combined comfort } \\
\text { parameters recommended } \\
\text { for change }\end{array}$} & Stall design & Reference & & $0.003 *$ \\
\hline & Stall size & 0.51 & $0.14,1.82$ & 0.297 \\
\hline & Floor characteristics & 4.20 & $1.20,16.06$ & 0.036 \\
\hline & Others & 0.26 & $0.09,0.77$ & 0.015 \\
\hline
\end{tabular}

*: Overall p-value 
Table 6: Description [median; (range)] of various outcomes and the significance of their differences within and between groups, preand post-intervention, using the Kruskal-Wallis test, in 73 smallholder farms in a cow comfort trial in Kenya, 2017

\begin{tabular}{|c|c|c|c|c|c|c|c|c|}
\hline \multirow[b]{2}{*}{ Outcome } & \multicolumn{3}{|c|}{ Intervention group $(n=90$ cows on 62 farms) } & \multicolumn{3}{|c|}{ Control group ( $\mathrm{n}=16$ cows on 11 farms) } & \multicolumn{2}{|c|}{$\begin{array}{l}\text { Differences between intervention and } \\
\text { control groups ( } P \text {-values) }\end{array}$} \\
\hline & $\begin{array}{l}\text { Pre- } \\
\text { intervention }\end{array}$ & $\begin{array}{l}\text { Post- } \\
\text { intervention }\end{array}$ & P-value & $\begin{array}{l}\text { Pre- } \\
\text { intervention }\end{array}$ & $\begin{array}{l}\text { Post- } \\
\text { intervention }\end{array}$ & $\begin{array}{l}\text { P- } \\
\text { value }\end{array}$ & Pre-intervention & Post-intervention \\
\hline Lying time (hrs) & $\begin{array}{l}10.85 \\
(2.89-19.02)\end{array}$ & $\begin{array}{l}11.45 \\
(6.28-19.82)\end{array}$ & 0.068 & $\begin{array}{l}10.38 \\
(5.75-14.96)\end{array}$ & $\begin{array}{l}10.61 \\
(6.67-19.82)\end{array}$ & 0.386 & 0.177 & 0.215 \\
\hline $\begin{array}{l}\text { Stall cleanliness } \\
\text { score }(1-5)\end{array}$ & $\begin{array}{l}2 \\
(1-5)\end{array}$ & $\begin{array}{l}2 \\
(1-5)\end{array}$ & 0.0001 & $\begin{array}{l}2 \\
(1.5-5)\end{array}$ & $\begin{array}{l}1.5 \\
(1-4)\end{array}$ & 0.122 & 0.616 & 0.794 \\
\hline $\begin{array}{l}\text { Udder } \\
\text { cleanliness } \\
\text { score }(1-5)\end{array}$ & $\begin{array}{l}2 \\
(1-4)\end{array}$ & $\begin{array}{l}2 \\
(1-3)\end{array}$ & 0.019 & $\begin{array}{l}2 \\
(1-3)\end{array}$ & $\begin{array}{l}1 \\
(1-3)\end{array}$ & 0.079 & 0.538 & 0.181 \\
\hline $\begin{array}{l}\text { Leg cleanliness } \\
\text { score }(1-5)\end{array}$ & $\begin{array}{l}2.75 \\
(1-5)\end{array}$ & $\begin{array}{l}2 \\
(1-4)\end{array}$ & 0.029 & $\begin{array}{l}2 \\
(1-4)\end{array}$ & $\begin{array}{l}2 \\
(1-4)\end{array}$ & 0.546 & 0.047 & 0.743 \\
\hline
\end{tabular}




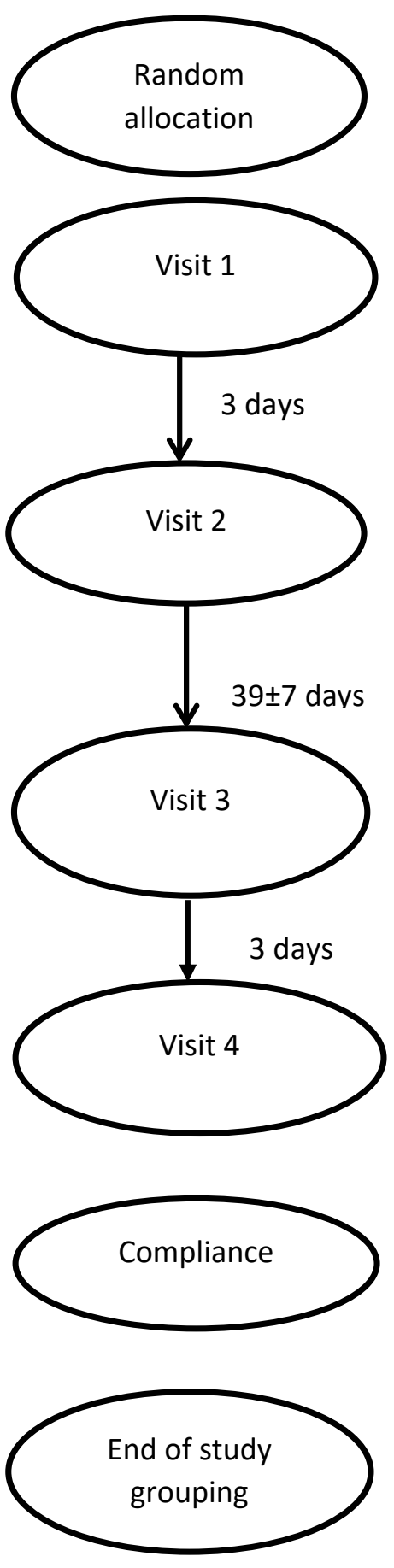

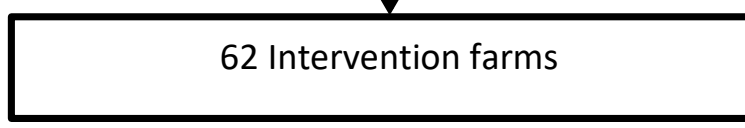

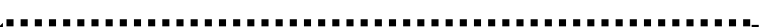

Baseline survey of cow, stall and farm status using observation and questionnaires

Attachment of data loggers to assess lying behaviour

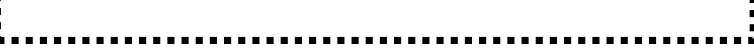

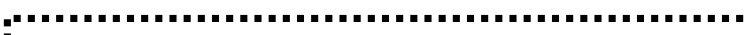

Removal of data loggers

Giving oral and written recommendations

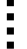

Compliance assessment

Post-intervention survey of cow, stall and

farm status using observation and questionnaires

Attachment of data loggers to assess lying
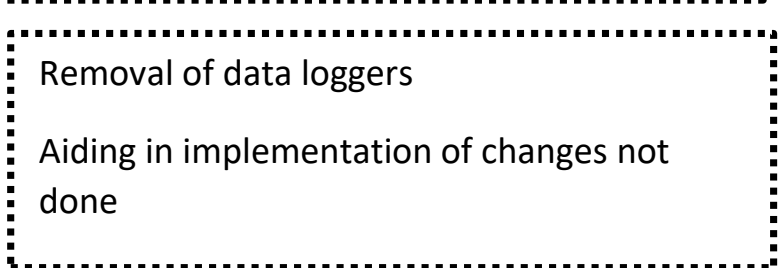

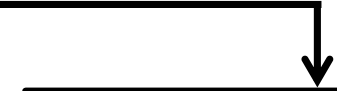

11 control farms

Baseline survey of cow, stall and farm status using observation and questionnaires

Attachment of data loggers to assess

lying behaviour

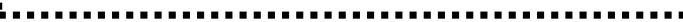

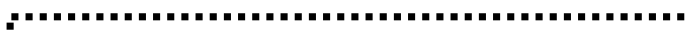

Removal of data loggers

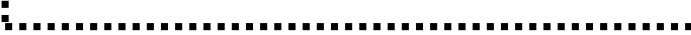

Post-intervention survey of cow, stall and farm status using observation and questionnaires

Attachment of data loggers

Removal of data loggers

Recommending and aiding in implementing cow comfort changes

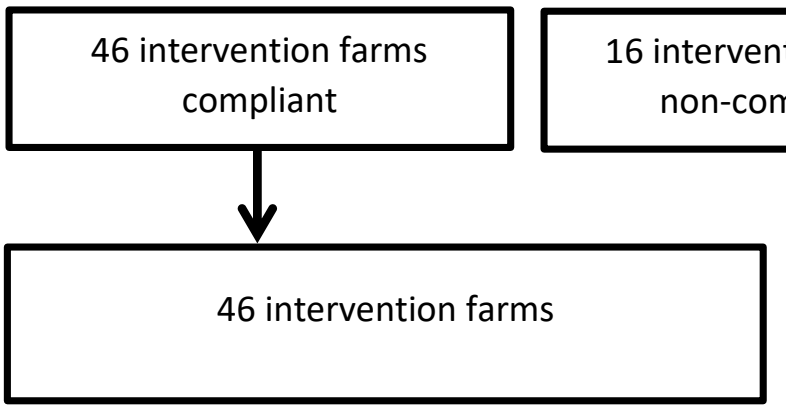

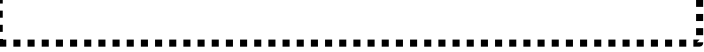

farms liant
11 control farms

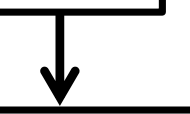

27 control farms

Fig. 1: Flow chart of 73 smallholder dairy farms enrolled in a randomized controlled trial in Meru, Kenya in 2017 


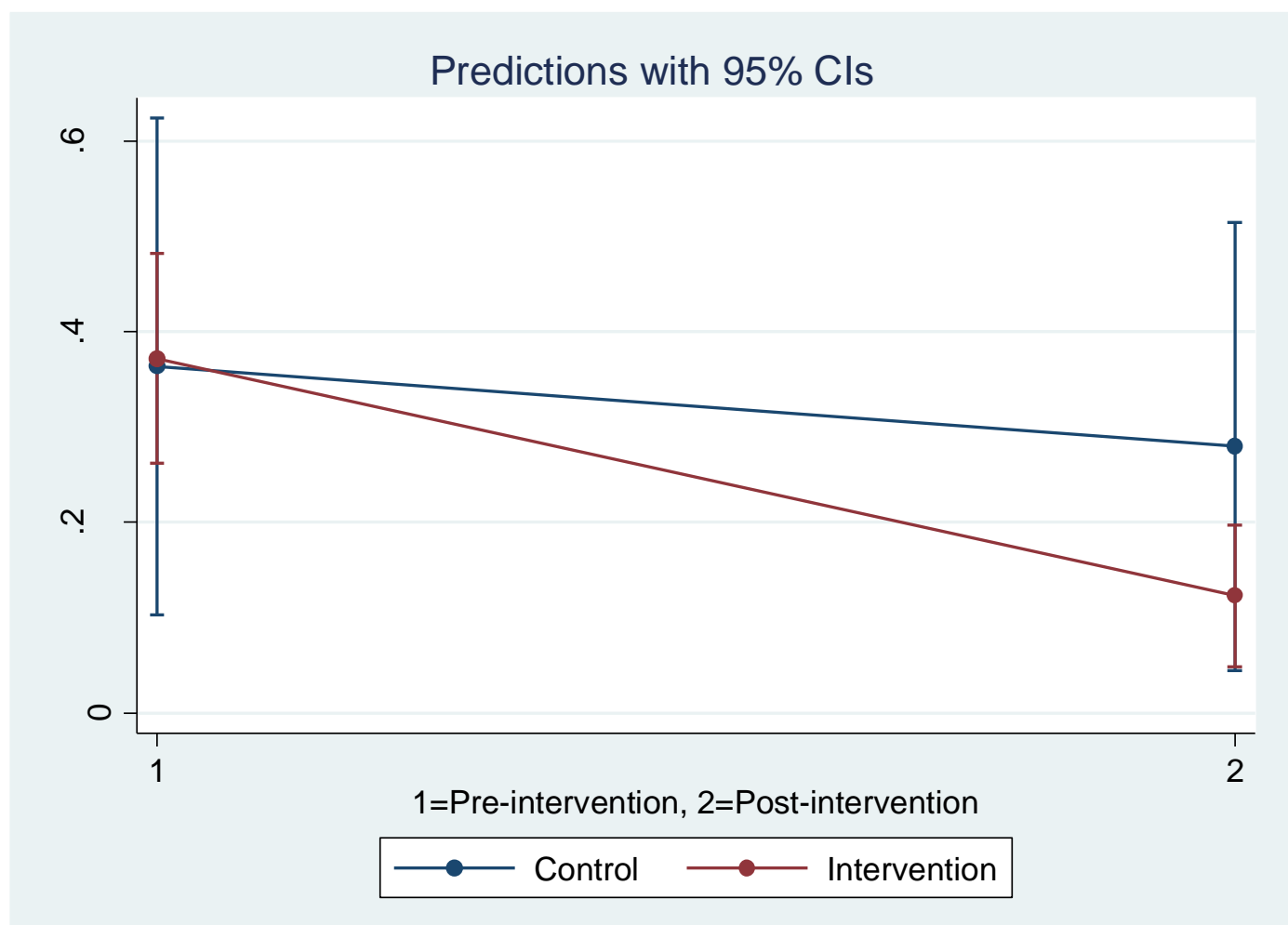

Fig. 2: Interaction effect between groups and visits on the proportion of dirty stalls in 103 cows on $70^{1}$ smallholder dairy farms in Meru, Kenya in 2017 ( ${ }^{1} 3$ cows on 3 farms had tethers rather than stalls in their zero-grazing compound) 


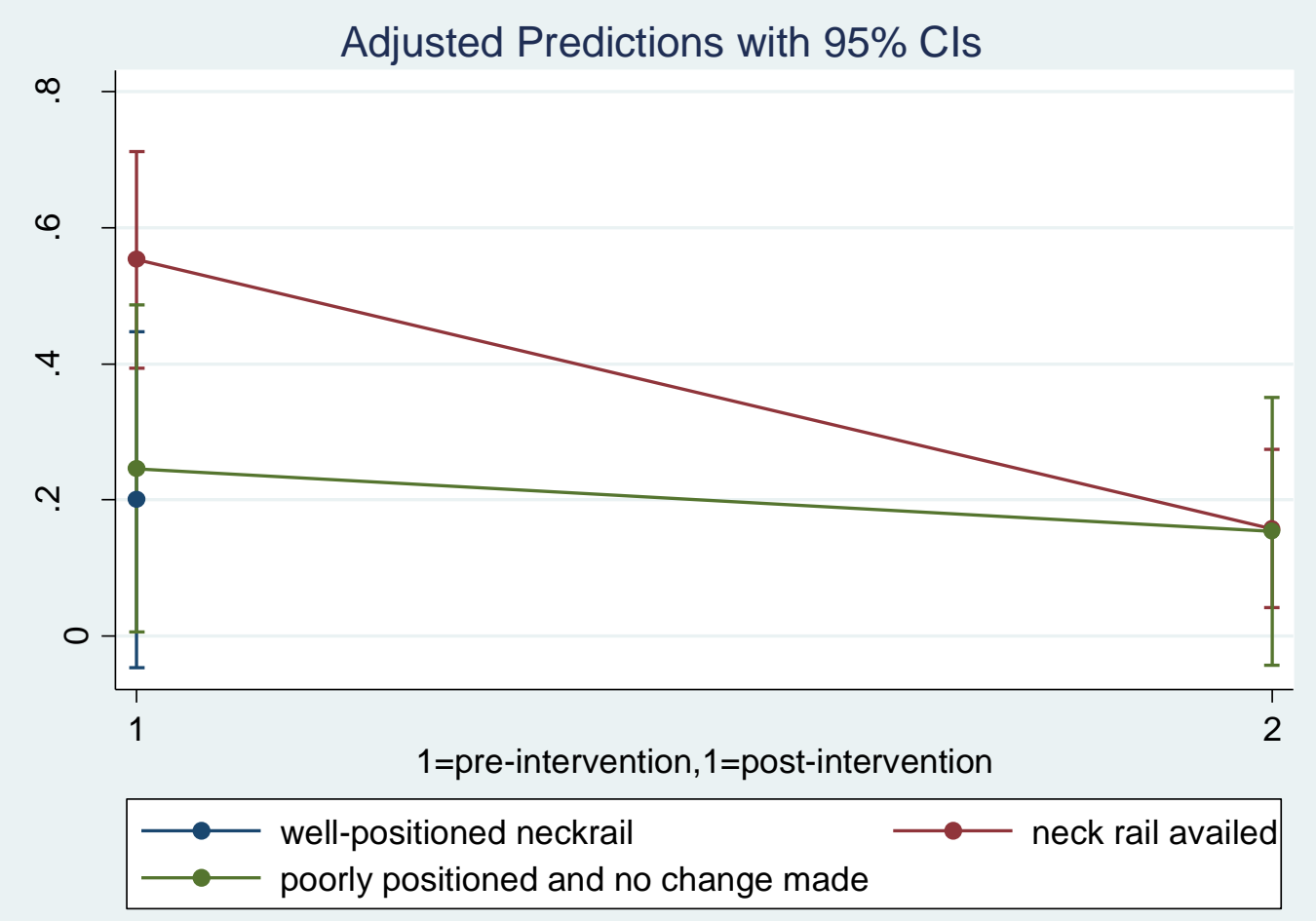

Fig. 3: Interaction effect between implementing neck rail changes proposed and visits on stall cleanliness of 90 cows in 62 smallholder dairy farms in Meru, Kenya in 2017 


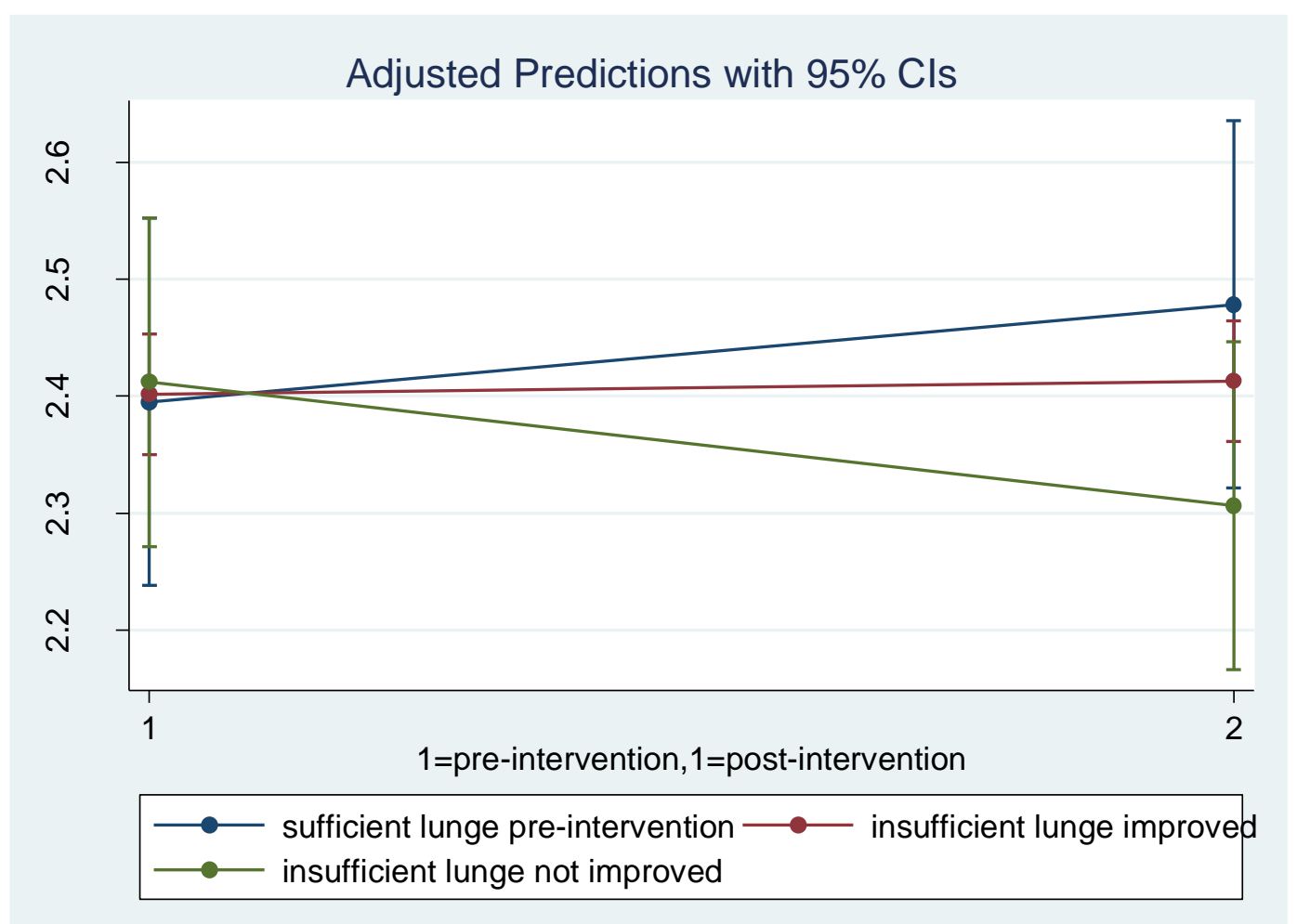

Fig. 4: Interaction plot of improving recommended changes on stall forward and /or side lunge space on log of lying time in 71 cows on 46 smallholder dairy farms in Meru, Kenya in 2017 